\title{
Characteristics of Mothers Which Affect The Low Coverage of Comprehensive Postpartum Service In The Working Area of Community Health Center of Kayen Kidul in Kediri Regency From January to August 2019
}

\author{
Dintya Ivantarina ${ }^{1}$, Lina Ratnawati ${ }^{2}$ \\ 1,2 Prodi D3 Kebidanan STIKES Karya Husada Kediri \\ Email: divantabelle25@gmail.com
}

\begin{abstract}
Abstrak
Pemanfaatan pelayanan ibu nifas secara paripurna di beberapa wilayah masih ada yang belum mencapai target yang telah ditetapkan oleh pemerintah. Beberapa faktor yang berpengaruh terhadap cakupan pelayanan ibu nifas paripurna yaitu karakteristik ibu. Tujuan penelitian ini untuk mengetahui karakteristik ibu yang mempengaruhi rendahnya cakupan pelayanan ibu nifas paripurna di Wilayah Kerja Puskesmas Kayen Kidul Kabupaten Kediri periode Januari-Agustus Tahun 2019. Penelitian ini dilakukan pada bulan September 2019 di Wilayah Kerja Puskesmas Kayen Kidul Kabupaten Kediri. Desain penelitian yang digunakan adalah observasional analitik dengan pendekatan case control. Teknik sampling yang digunakan yaitu cluster random sampling. Sampel dalam penelitian ini adalah ibu yang sudah selesai melewati masa nifasnya (lebih dari 6 minggu sampai 9 bulan setelah melahirkan). Variabel independen yaitu karakteristik ibu sedangkan variabel dependen yaitu cakupan pelayanan ibu nifas paripurna. Pengumpulan data menggunakan lembar pengumpulan data dengan teknik wawancara terstruktur dan rekam medik berupa buku KIA. Kemudian data diolah dan dianalisis secara univariate, bivariate dan multivariate. Hasil uji statistik bivariat menunjukkan bahwa pekerjaan $(p=0,023)$, komplikasi kehamilan $(p=0,026)$, komplikasi persalinan $(p=0,03)$ dan jenis persalinan $(p=0,01)$ memiliki pengaruh terhadap rendahnya cakupan pelayanan ibu nifas paripurna. Hasil uji statistik multivariat dengan menggunakan regresi logistik binomial didapatkan hasil pada Table omnibus memiliki $p=0,006(p<0,05)$ yang berarti model layak dianalisis. Nilai signifikansi pada Table Hosmer and Lemeshow Test sebesar 0,074 $(p>0,05)$ memiliki arti model dapat diterima dan pengujian hipotesis dapat dilakukan. Nilai Nagelkerke $R$ Square sebesar 0,278 artinya karakteristik ibu yaitu usia $(p=0,047)$ dan jenis persalinan $(p=0,037)$ memiliki pengaruh sebesar $27,8 \%$ terhadap rendahnya cakupan pelayanan ibu nifas paripurna. Program kebijakan kesehatan masyarakat harus bertujuan untuk meningkatkan cakupan pelayanan ibu nifas paripurna dengan memperhatikan karakteristik ibu di wilayah tersebut yaitu karakteristik usia ibu dan jenis persalinan.
\end{abstract}

Kata Kunci: karakteristik, cakupan, ibu nifas paripurna

\begin{abstract}
The utilization of postpartum maternal services in a complete manner in several regions still has not reached the target that has set by the government. Some factors that affect the coverage of comprehensive postpartum service is mother characteristics. The purpose of this research is to determine the characteristics of mothers who affect the low coverage of comprehensive postpartum service in the working area of Community Health Center of Kayen Kidul in Kediri Regency from January to August year 2019. This research was conducted in September 2019 in the working area of Kayen Kidul Community Health Center of in Kediri Regency. The design of the research used is analytical observational with a case control approach. The sampling techniques used are random sampling clusters.
\end{abstract}


The samples in this study were mothers who had finished their postpartum period (more than 6 weeks to 9 months after giving birth). Independent variables are characteristic of mothers while dependent variables are coverage of the comprehensive postpartum service. Collection of data using data collection sheets with structured interview techniques and medical records in the form of maternal and child health books. Then the data is processed and analyzed univariate, bivariate and multivariate. Statistical results of bivariate statistics showed that the work $(P=0.023)$, pregnancy complications $(P=0.026)$, labor complications $(P=0.03)$ and the type of childbirth $(P=0.01)$ have an influence on the low coverage of comprehensive postpartum service. Multivariate statistical test results using binomial logistic regression obtained results in the omnibus table having $P=0.006$ $(P<0.05)$ which means the model is worth analysed. The significance value in the Hosmer and Lemeshow Test table of $0.074(p>0.05)$ has the meaning of acceptable models and hypothesis testing can be performed. The value of Nagelkerke $R$ Square 0.278 means the characteristic mother of age $(P=0.047)$ and the type of childbirth $(P=0.037)$ has an effect of $27.8 \%$ on the low coverage of the comprehensive postpartum service. The public health policy program should aim to improve the coverage of the comprehensive postpartum service by observing the characteristics of mothers in the region, namely the characteristics of maternal age and type of delivery.

Keywords: characteristic, coverage, postpartum mother comprehensive

Article info:

Article submitted on September 15, 2019

Articles revised on October 10, 2019

Articles received on November 26, 2019

DOI: http://dx.doi.org/10.21927/jnki.2019.7(3).172-183

\section{INTRODUCTION}

Maternal Mortality Rate (MMR) is an approach to improve maternal health and end maternal mortality which is used as a reference in several countries to determine strategies for the prevention and control of maternal mortality (1). The reduction of MMR has long been a global health priority with targets set in accordance with the Millennium Development Goals of $75 \%$ (MDGs) (2). When the MDGs ended in September 2015 the number of maternal deaths worldwide declined by $44 \%$ from 1990 to 2015 so that the target for a reduction in the MMR of the world by $75 \%$ was not achieved (3). In fact, most countries fail to reach the MDGs target to reduce maternal mortality (4).

The improvement of the MDGs target that was not achieved, prompted WHO to continue the MDGs program to become the Sustainable Development Goals (SDGs) program adopted by countries in the world and launched at the end of 2015 (5). One of the SDGs targets at the global and country level is to reduce maternal mortality by 70 maternal deaths per 100,000 up to 2030 , each country must reduce the maternal mortality ratio at least two-thirds from the 2010 baseline, and no country has a higher maternal mortality rate of 140 deaths per 100,000 live births (twice the global target) (6).

The results of the 2015-2017 Health Ministry of Indonesia Performance Report show that the number of maternal deaths in 2016 decreased from 4999 in 2015 to 4912 and in 2017 the number of maternal deaths was reported as many as $1712(7)$. The data from East Java Provincial Health Office in 2017 showed that there were 457 maternal deaths per 100,000 live births. The biggest cause of maternal death was preeclampsia $29 \%$ or 154 cases, other causes $29 \%$ or 154 cases, bleeding $26.28 \%$ or 130 cases 
and infections $3.59 \%$ or as many as 19 cases (8). While data from the Kediri District Health Office in 2018 showed the number of maternal deaths as many as 17 people, where the number has increased compared to 2017, which was 15 people. The cause of maternal death from 2017 to 2018 did not change where bleeding was $50 \%$, followed by severe preeclampsia was 33\%, heart disease was $17 \%$ and ileus was $12.5 \%$ (9).

Postpartum hemorrhage is the leading cause of maternal and infant morbidity and mortality worldwide with $25-30 \%$ of all maternal deaths with an estimated 127,000 deaths each year (10). Postpartum hemorrhage is often classified into two namely primary postpartum hemorrhage occurring within 24 hours after delivery (11) and secondary postpartum hemorrhage as bleeding that exceeds normal lochia after 24 hours of labor for up to six weeks postpartum (12). The incidence of primary postpartum hemorrhage is $5 \%$ while secondary postpartum hemorrhage is 0.5 to $1.3 \%$ (13). The lower incidence of secondary postpartum hemorrhage compared to primary postpartum hemorrhage received little attention among obstetricians and other health professionals. The main danger for patients is that bleeding occurs mostly between first and second weeks after giving birth when the patient is often at home and is unaware that the secondary postpartum hemorrhage is also potentially life-threatening (14).

One of strategy to detect early and prevent secondary bleeding is by utilizing postpartum services. Postpartum care services at least four times, namely on the 6-8 hours, the sixth day, the second week after and six weeks after delivery includes physical examination (vital signs, breasts, uterine fundus, lochia and other vaginal expulsion), communication or information or education about exclusive breastfeeding and family planning (15). In Indonesia, the coverage of comprehensive postpartum visits showed an increase from 2008 by $17.9 \%$ to $87.36 \%$ in
2017. In East Java Province the coverage of comprehensive postpartum visits was $92.84 \%$ (16). Achievements of comprehensive services for postpartum in Kediri increased in 2018 compared to 2017. In 2018, coverage of comprehensive postpartum service was $90.3 \%$ while in 2017 it was $74.69 \%$ of 38 public health centers (9). The Local Monitoring Data for Mother and Child Health Kayen Kidul Community Health Center in January to August 2019 there are several villages where the achievement of comprehensive postpartum service coverage has not met the target including Jambu village by $40 \%$ and Sekaran village by $53.84 \%$ of the target January-August 2019 was $66.6 \%$ (17).

Some factors that influence the coverage of comprehensive postpartum services are midwives, health services and maternal characteristics. The characteristics of the mother are affected by the sensitivity about the importance of postpartum care (18). Such sensitivity is influenced by predisposing characteristic, enabling characteristics and characteristic needs. Predisposing characteristics consist s of age, parity, marital status, education, employment, communication, community and peer service use. Then, nabling characteristics consists of distance to health facilities, health service costs, and health systems that support the community. While, need Characteristics consists of antenatal, labor and postnatal complications, delivery, the need of contraceptive and HIV testing (19). The results of previous studies indicate that education level, pregnancy distance, attitudes and perceptions of mothers have a significant relationship to the intention of the puerperal mothers to make puerperal visits to health services (20). In addition, it is also supported by other studies that show predisposing factors (age, income and knowledge); enabling factors (urban living, ease of access to health) and need factors (complications of pregnancy and types of childbirth) are significantly associated with 
increased use of postnatal care in the country of Ethiopia (21).

Based on the problem of comprehensive postpartum services coverage above that has not met the target, the researcher is interested in analyzing and examining more about maternal characteristics, specifically enabling and need characteristics that affect the low postpartum maternal services in the Kayen Kidul Health Center in Kediri Regency in the January-August year period 2019.

\section{MATERIALS AND METHODS}

This study uses an analytic observational research design with a case control approach. This research was conducted in September 2019 in the working area of Kayen Kidul Community Health Center in Kediri Regency. The population in this study were mothers who had finished their postpartum period (more than 6 weeks to 9 months after giving birth) in the working area of Kayen Kidul Community Health Center in Kediri District. As many as 273 mothers were taken from villages whose coverage of comprehensive postpartum services had the low coverage and appropriate coverage target between JanuaryAugust 2019. This research sample is divided into two, namely case samples and control samples with a ratio of 1:1 that fulfill the inclusion and exclusion criteria. Case samples in this study are mothers who had finished their postpartum period (more than 6 weeks to 9 months after giving birth) from villages whose coverage of comprehensive postpartum services has not met the target, namely Jambu and Sekaran villages, as many as 42 respondents. While, control samples are taken from villages whose coverage of postnatal comprehensive services has fulfilled the target, namely the villages of Padangan, Nanggungan and Sukoharjo as many as 42 respondents. The sampling technique used is cluster random sampling. The independent variable is the characteristics of the mother while the dependent variable is the coverage of comprehensive postpartum services. Data collection sheets are used with structured interview techniques and medical records in the form of a maternal and child health book. The data that has been collected is processed through the stages of editing, coding and tabulating. Data analysis was performed univariate analysis with percentages of each category to describe the characteristics of each variable. Bivariate analysis using Chi Square test while multivariate data analysis using multiple logistic regression statistical tests.

\section{RESULTS AND DISCUSSION \\ Characteristics of Mother}

Based on Table 1, the frequency distribution of maternal characteristics in the working area of Kayen Kidul Community Health Center in Kediri Regency in the January-August 2019 period, it can be seen that the majority of respondents of which service coverage target for comprehensive postpartum services is not fulfilled, those aged $20-35$ years are 30 respondents $(71.4 \%)$, those with basic education (elementary and junior high) were 22 respondents (52.4\%), who did not work were 36 respondents (85.7\%), multigravida 22 respondents $(54.8 \%)$, who did not experience complications during pregnancy as many as 42 respondents (100\%), who did not experience childbirth complications 39 respondents (92.9\%), who did not experience postpartum complications were 42 respondents (100\%), and those who gave birth normally were 39 respondents (92.9\%).

While the group of respondents whose target coverage for comprehensive postpartum services was fulfilled most had an age that was not at risk (20-35 years). Namely as many as 37 respondents (88.1\%). Those with basic education (elementary and junior high school) were 17 respondents $(40.5 \%)$, who did not work 27 respondents (64.3\%), who were primigravida 26 respondents $(61.9 \%)$, who did not experience pregnancy 
complications 36 respondents (85.7\%), who did not experience childbirth complications as many as 28 respondents $(66.7 \%)$, who did not experience postpartum complications were 42 respondents $(100 \%)$, and those who gave birth normally were 30 respondents $(71.4 \%)$.

Table 1 . Frequency Distribution of Mother's Characteristics in the Work Areas of Kayen Kidul Community Health Center in Kediri Regency in th January-August 2019

\begin{tabular}{|c|c|c|}
\hline \multirow[t]{2}{*}{ Variable } & $\begin{array}{c}\text { Low } \\
\text { Coverage } \\
\end{array}$ & $\begin{array}{c}\text { Appropriate } \\
\text { Coverage }\end{array}$ \\
\hline & n (\%) & n (\%) \\
\hline \multicolumn{3}{|l|}{ Mother's age } \\
\hline Risky & $12(28.6 \%)$ & $5(11.9 \%)$ \\
\hline No risk & $30(71.4 \%)$ & $37(88.1 \%)$ \\
\hline \multicolumn{3}{|l|}{ Education } \\
\hline Basic & $22(52.4 \%)$ & $17(40.5 \%)$ \\
\hline High school & $17(40.5 \%)$ & $17(40.5 \%)$ \\
\hline College & $3(7.1 \%)$ & $8(19 \%)$ \\
\hline \multicolumn{3}{|l|}{ Job } \\
\hline Employed & $6(14.3 \%)$ & $15(35.7 \%)$ \\
\hline Unemployed & $36(85.7 \%)$ & $27(64.3 \%)$ \\
\hline \multicolumn{3}{|l|}{ Parity } \\
\hline Primigravida & $19(45.2 \%)$ & $26(61.9 \%)$ \\
\hline Multigravida & $23(54.8 \%)$ & $16(38.1 \%)$ \\
\hline \multicolumn{3}{|c|}{ Pregnancy Complications } \\
\hline Yes & 0 & $6(14.3 \%)$ \\
\hline No & $42(100 \%)$ & $36(85.7 \%)$ \\
\hline \multicolumn{3}{|c|}{ Labor Complications } \\
\hline Yes & $3(7.1 \%)$ & $14(33.3 \%)$ \\
\hline No & $39(92.9 \%)$ & $28(66.7 \%)$ \\
\hline \multicolumn{3}{|c|}{ Postpartum Complications } \\
\hline Yes & 0 & 0 \\
\hline No & $42(100 \%)$ & $42(100 \%)$ \\
\hline \multicolumn{3}{|l|}{ Type of Childbirth } \\
\hline Normal & $39(92.9 \%)$ & $30(71.4 \%)$ \\
\hline SC & $3(7.1 \%)$ & $12(28.6 \%)$ \\
\hline Total & $42(100 \%)$ & $42(100 \%)$ \\
\hline
\end{tabular}

Relationship between Mother Characteristics and Comprehensive Postpartum Services Coverage

Based on Table 2 shows that job $(p=0.023)$, pregnancy complications $(p=0.026)$, delivery complications $(p=0.03)$ and type of delivery ( $p=0.01$ ) have a significant effect on the low coverage of comprehensive postpartum services in the Kayen Kidul Community Health Center in Kediri Regency in the January-August 2019 period $(p<0.05)$. Age $(p=0.057)$, education ( $p$
$=0.274)$ and parity $(p=0.126)$ did not have a significant effect on the low coverage of comprehensive postpartum services in the Kayen Kidul Community Health Center in Kediri Regency in the January-August 2019 period $(p>0.05)$. Postpartum complications cannot be analyzed because the bivariate statistic examination requirements are not met.

\section{The Effect of Job on Low Coverage of Comprehensive Postpartum Services}

The results of the analysis show that the mother's work significantly influences the low coverage of comprehensive postpartum services. Working mothers, earning more tend to be economically independent so that they have access to health services and utilize health services when they are in need or as recommended by health workers such as midwives (22). Previous studies by Mohan et al (2015) in Tanzania also support the results of this study that mothers from wealthy households are more likely to receive postnatal care services and immediate postnatal care. This result can be explained by the availability of funds to spend in the hospital to give birth and get further services such as postpartum services. Likewise, working mothers are always associated with having a household with a higher socioeconomic category and are also more likely to realize the benefits of obtaining postnatal care services through different media such as television and newspapers than their colleagues from the unemployed group and included in the low socioeconomic category (19).

\section{The Effect of Pregnancy Complications on Low Coverage of Comprehensive Postpartum Services}

The analysis showed that pregnancy complications had a significant effect on the low coverage of comprehensive postpartum services. The results of this study are consistent 
Table 2. Effect of Maternal Characteristics on the Coverage of Comprehensive Postpartum Services in the Kayen Kidul Community Health Center in Kediri Regency January-August 2019

\begin{tabular}{|c|c|c|c|c|c|c|c|}
\hline \multirow{3}{*}{ Variable } & \multicolumn{6}{|c|}{ Coverage of Comprehensive Postpartum Services } & \multirow{3}{*}{$P$. } \\
\hline & \multicolumn{2}{|c|}{ Corresponding } & \multicolumn{2}{|c|}{ Inappropriate } & \multicolumn{2}{|c|}{ Total } & \\
\hline & $\mathbf{n}$ & $\%$ & $\mathbf{n}$ & $\%$ & $\mathbf{n}$ & $\%$ & \\
\hline \multicolumn{8}{|l|}{ Age } \\
\hline Risky & 5 & 6 & 12 & 14.3 & 17 & 20.2 & 0,057 * \\
\hline No risk & 37 & 44 & 30 & 35.7 & 67 & 79.8 & \\
\hline \multicolumn{8}{|l|}{ Education } \\
\hline Basic & 17 & 20.2 & 22 & 26.2 & 39 & 46.4 & 0,274 * \\
\hline High & 25 & 29.8 & 20 & 23.8 & 45 & 53.6 & \\
\hline \multicolumn{8}{|l|}{ Job } \\
\hline Employed & 15 & 17.9 & 6 & 7.1 & 21 & 25 & 0,023 * \\
\hline Unemployed & 27 & 32.1 & 36 & 42.9 & 63 & 75 & \\
\hline \multicolumn{8}{|l|}{ Parity } \\
\hline Primigravida & 26 & 31 & 19 & 22.6 & 45 & 53.6 & 0,126 * \\
\hline Multigravida & 16 & 19 & 23 & 27.4 & 39 & 46.4 & \\
\hline \multicolumn{8}{|c|}{ Pregnancy Complications } \\
\hline Yes & 6 & 7.1 & 0 & 0 & 7.1 & 7.1 & 0,026 ** \\
\hline No & 36 & 42.9 & 42 & 50 & 78 & 92.9 & \\
\hline \multicolumn{8}{|l|}{ Labor Complications } \\
\hline Yes & 14 & 16.7 & 3 & 3.6 & 17 & 20.2 & $0.03^{*}$ \\
\hline No & 28 & 33.3 & 39 & 46.4 & 67 & 79.8 & \\
\hline \multicolumn{8}{|c|}{ Postpartum Complications } \\
\hline Yes & 0 & 0 & 0 & 0 & 0 & 0 & Not \\
\hline No & 42 & 50 & 42 & 50 & 84 & 100 & analyzed \\
\hline \multicolumn{8}{|l|}{ Type of Childbirth } \\
\hline Normal & 30 & 35.7 & 39 & 46.4 & 69 & 82.1 & $0.01 *$ \\
\hline SC & 12 & 14.3 & 3 & 3.6 & 15 & 17.9 & \\
\hline
\end{tabular}

with the results of research conducted by Ulfa, Kuswardinah and Mukarromah (2018) that needs has an effect of $11.9 \%$ on the sustainable utilization of maternal health services with a significance level of $0.048(p<0.05)$ (23). Mothers who experience complications or suffer illness during pregnancy are more likely to visit health workers during pregnancy to find out and get antenatal care than mothers who have no problems or complications or suffer from illness during pregnancy unless there are other supporting reasons that encourage mothers to check their pregnancy at health workers. Lack of maternal visits in examining pregnancy will affect the labor process including the place, helper and type of childbirth as well as influencing the concern for getting postpartum maternal care.
In some countries mothers who rarely check for pregnancy are afraid of being reprimanded by health workers and lacking information about pregnancy, childbirth and postpartum services in accordance with standards so that they will choose to give birth at home. While mothers who give birth at home will also miss the importance of childbirth care services related to health checks for fear of being reprimanded by health workers and do not receive information about postpartum care. Complications of pregnancy will have an impact on antenatal care visits which later with antenatal care visits bring positive results to the entire set of treatments including the delivery process and health visits during the postpartum period (24). 
The Effect of Childbirth Complications on Low Coverage of Comprehensive Postpartum Services

The analysis showed that childbirth complications had a significant effect on the low coverage of comprehensive postpartum services. The use of postpartum services is higher in women who experience problems during labor. Mothers who experience complications with labor will end in labor such as cesarean section or forceps delivery so that they are more likely to come for postpartum services as part of follow-up care for their complications (19). This is similar to the results of previous studies in Northwest Ethiopia which showed the same results. Conformity of the results of this study with previous research explained that the coverage of comprehensive postpartum services who did not meet the target of the majority of respondents did not experience complications during delivery. Hence, the impact was not very enthusiastic to get postpartum care services (22).

\section{The Effect of Type of Childbirth on Low Coverage of Comprehensive Postpartum} Services

The analysis showed that the type of delivery had a significant influence on the low coverage of comprehensive postpartum services. The results of this study are consistent with the results of a study conducted by Berhe et al (2019) about the factors that affect postpartum mothers in accessing postpartum maternal health services in Tigray Northwest Ethiopia which show results that mothers are most likely to receive postnatal care when giving birth in childbirth cesarean section (OR 2.88 95\% Cl 1.32, 6.29) which means that cesarean section increases the risk by 2.88 or 3 times more to utilize postpartum maternal care compared to vaginal delivery (22).

The results of this study indicate that in the coverage of comprehensive postpartum services that is not on target the majority of respondents have normal vaginal delivery and are supported by different studies from Ethiopia and Tanzania that the type of cesarean delivery provides increased opportunities to utilize complete postpartum care. This can happen because women who undergo cesarean section tend to have greater susceptibility to various postoperative complications, causing mothers to return often to check their health conditions to health workers to minimize the risk of complications to be experienced (25).

\section{The Effect of Age on Low Coverage of Comprehensive Postpartum Services}

The results showed that maternal age did not significantly influence the low coverage of comprehensive postpartum services. The uninfluential of maternal age on the low coverage of comprehensive postpartum services is likely to be caused by the majority of respondents at the age of not at risk (20-35 years) so that they do not think that they need full postpartum care services. The results of this study are supported by research conducted by Pinaringsih, Riyanti and Kusumawati (2017) in the Work Area of Tlogosari Kulon Health Center in Semarang City which shows that age has no relationship with intention to carry out postpartum visits ( $p$ $=0.473)$. Where in the results of the study the majority of mothers with ages 20-34 years did not use or carry out visits to get postpartum services (20). The results of this study are also in line with research conducted in rural areas of four districts in the Morogoro Region in Tanzania such as Morogoro, Mvomero, Kilosa and Ulanga District Councils showing maternal age was not a significant predictor influencing mothers to use postpartum maternal services completely (19).

\section{The Effect of Education on Low Coverage of Comprehensive Postpartum Services}

The analysis showed that education did not significantly influence the low coverage of 
comprehensive postpartum services. The results of this study are not in line with the results of previous studies which showed a striking variation in the use of childbirth services in accordance with the education level of the respondents being investigated (26). This is because women who have higher education have the autonomy and decision-making skills on health and utilization of health care services. Likewise, uneducated women do not have the opportunity to participate in social and economic positions, decision making and women's empowerment. In addition, education helps increase the level of awareness of mothers and their acceptance of new ideas and provides better education for other women regarding the use of childbirth care services (27).

In this study, education did not significantly influence the low coverage of comprehensive postpartum services, probably because the majority of respondents had a high school education. Even though high school education is included in the higher education category, it cannot be stated the same as respondents with tertiary education, whereas in this study, respondents who had the last tertiary education were very few. In addition, from three studies that conducted research on the relationship between maternal schooling and the use of childbirth services, it was found to have a positive correlation. The longer a mother attends school the possibility of using postpartum maternal services is higher. Mothers who took basic education compared to women who did not get formal education were more likely to use services during the puerperium. Likewise, women who have completed senior secondary education are the most likely to access services in the puerperium (28). The results of this study are consistent with research conducted in the country of Ethiopia which shows that there is no relationship between the use of postnatal care services and maternal education at the elementary and secondary school levels compared with mothers who take informal education or do not take education (21).

\section{The Effect of Parity on Low Coverage of Comprehensive Postpartum Services}

The analysis showed that parity did not significantly influence the low coverage of comprehensive postpartum services. Primiparity is another determinant for using postpartum care services in full. Studies in Ethiopia and Nepal have shown consistent findings that primiparous mothers usually depend on the support of health professionals and their families for baby care and breastfeeding practices. Likewise, they will be very curious about the health of their newborns, thus this need can be met through frequent contact with health workers repeatedly $(25,29)$. Another theory states that mothers who have four children and above are less likely to take advantage of childbirth care services compared to mothers who have one child. The results of this study are supported by research conducted in the country of Northern Ethiopia where the utilization of postnatal care services is decreasing because the number of pregnancies is increasing. Mothers who have 4 or more pregnancies are less likely to utilize postnatal care services compared to primigravida (30).

In this study, respondents who were in the postpartum maternal services range were not in accordance with the target, most were classified as multigravida with the majority of children 2 (not including the category of high parity) and were at reproductive age or not at risk (20-35 years) so that mothers not concerned with the number of childbirth care services obtained and supported by the absence of complications during the puerperium causes mothers feel they do not need childbirth care. These results are in line with research conducted in the Tlogosari Community Health Center Work Area of the City of Semarang under the title Factors Related to the Intention of Postpartum Mother's Visit 
to Health Services shows that parity has no relationship with intention to carry out postpartum visits $(p=0.481)(p=0.481)(20)$.

\section{The Effect of Postpartum Complications on Low Coverage of Comprehensive Postpartum Services}

In the results of this study the effect of postpartum complications on the low coverage of comprehensive postpartum services cannot be analyzed by bivariate statistical tests because in case and control groups $100 \%$ of respondents had never experienced postpartum complications. This result is not in accordance with previous research which shows the perception of postpartum mothers to postpartum health affect the use of sustainable maternal health services (23). The difference in these results with previous similar studies is likely due to the researchers not asking specifically about the complaints that were felt during childbirth to the respondent. The complication of childbirth in question is aimed more at problems during the life-threatening childbirth. During the puerperium, mothers often suffer more than one physical disorder or discomfort after giving birth such as stress incontinence, perineal pain, breast problems, back pain, hemorrhoids and constipation throughout the world as well as in China. Postnatal depression is one of the most frequent psychological disorders that also affects the lives and well-being of postpartum mothers and families. The reported prevalence of postnatal depression is around $10-15 \%$ worldwide and an average of $14.7 \%$ in China. Most studies report that many mothers do not report physical or psychological problems to health workers or even to their family members who indicate that these mothers should receive more care as needed during the postnatal period (31). So that there are problems in the postpartum in the form of psychological and psychological problems are not considered by the mother as a complication during the postpartum who need to get postpartum maternal care in a complete manner.

\section{Dominant Variables of Mother Characteristics Related to Comprehensive Postpartum Services Coverage}

The results of multivariate statistical tests using binomial logistic regression based on table 3 obtained the results in the omnibus table having $p=0.006(p<0.05)$ which means that the model is feasible to be analyzed or the independent variables can have a real influence on the formation of the model. The significance value in the Hosmer and Lemeshow Test table of $0.074(p>0.05)$ means that the model can be accepted and hypothesis testing can be done because there is no significant difference between the model and its observation value. Nagelkerke R Square value of 0.278 means that maternal characteristics, namely age $(p=0.047)$ and type of delivery ( $p=0.037)$ have an effect of $27.8 \%$ on the low coverage of comprehensive

Table 3 Characteristics of Mothers Most Influential to the Coverage of Comprehensive Postpartum Services in the Kayen Kidul Community Health Center in Kediri Regency January-August 2019

\begin{tabular}{|c|c|c|c|c|c|c|c|}
\hline \multirow{2}{*}{ Variable } & \multirow{2}{*}{$\operatorname{Exp}(B)$} & \multicolumn{2}{|c|}{$95 \% \mathrm{Cl}$ for $\operatorname{Exp}(\mathrm{B})$} & \multirow{2}{*}{$P$ value } & \multirow{2}{*}{ Ket } & \multirow{2}{*}{ Omnibus (Sig.) } & \multirow{2}{*}{$\mathbf{R}^{2}$} \\
\hline & & Lower & Upper & & & & \\
\hline Age & .243 & 0.060 & 0.984 & 0.047 & Significant & 0.006 & 0.278 \\
\hline Education & 0.724 & 0.267 & 1.968 & 0.527 & Not significant & & \\
\hline Work & 2.775 & 0.780 & 9.870 & 0.115 & Not significant & & \\
\hline Parity & 1.888 & 0.708 & 5.033 & 0.204 & Not significant & & \\
\hline Pregnancy complications & 6.103 & 0.511 & 72.891 & 0.153 & Not significant & & \\
\hline Labor Complications & 0.614 & 0.100 & 3.774 & 0.598 & Not significant & & \\
\hline Type of Childbirth & .137 & 0.021 & .884 & 0.037 & Significant & & \\
\hline
\end{tabular}


postpartum services while $72.2 \%$ is influenced by other factors.

\section{Characteristics of Mothers Who Are Most Influential About Low Coverage of Comprehensive Postpartum Services}

The results of multivariate analysis with binomial logistic regression showed age (predisposing characteristics) and type of delivery (need characteristics) had a significant effect of $27.8 \%$ on the low coverage of comprehensive postpartum services while $72.2 \%$ were influenced by other factors. The results of this study are in accordance with the results of the logistic regression test regarding the factors that influence the sustainable use of maternal health services with a sample of postpartum mothers showing predisposing factors have an effect of $20.2 \%$, enabling factors have an effect of $3.5 \%$ with an improper model analyzed and need factors have an effect of $11.9 \%$ (23). While other factors are likely to be influenced by midwives (midwife characteristics and service quality) and health services (health facilities and tools or medicines) (18). Supported by previous research conducted in the villages of Klaten Regency, Central Java Province, showed three categories of barriers to the use of postnatal services in the village, namely the knowledge of mothers and family members about postpartum services, sociocultural beliefs and practices, and health service responses (15).

Bivariate analysis results different from multivariate analysis. In the bivariate analysis: occupational variables, pregnancy complications, delivery complications and type of childbirth had a significant effect on the low coverage of comprehensive postpartum services in the working area of the Kayen Kidul Community Health Center while in the multivariate analysis only the age and type of delivery had a significant effect. This is likely because when all the variables are entered together at the time of the statistical test a regression has an influence or forms a different model compared to testing each variable. Another possibility is caused there are his other variables that cause the relationship between variables is very little or no mediator or moderator variables that are not included in the study. In addition, based on the results of multivariate analysis showed age (predisposing characteristics) and the type of delivery (need characteristics) have a significant influence amounted to $27.8 \%$ of the low coverage of comprehensive postpartum services while there are $72.2 \%$ are influenced by other factors. This could be because the variables studied were only in terms of predisposing characteristics and need characteristics, while in theory the coverage of comprehensive postpartum services was also influenced by enabling characteristics.

\section{CONCLUSION AND RECOMMENDATION}

The low coverage of comprehensive postpartum services in the working area of Kayen Kidul Community Health Center in Kediri Regency in the January-August 2019 period is affected by work, pregnancy complications, delivery complications and types of childbirth. The factors that most influence the low coverage of comprehensive postpartum services in the Kayen Kidul Community Health Center are age and type of delivery. Public health policy programs should aim to increase the coverage of comprehensive postpartum services by paying attention to the characteristics of mothers in the region by taking into account predisposing characteristics and need characteristics through education and empowering women with skills that can help them make the right decisions and adequate livelihoods. Further, the researchers are advised to conduct research by considering all the factors that influence the low coverage of comprehensive postpartum services such as midwives, available health services, and maternal characteristics so that a good model of factors 
influencing the low coverage of comprehensive postpartum services can be obtained.

\section{REFERENCES}

1. Smith $\mathrm{H}$, Ameh $\mathrm{C}$, Roos $\mathrm{N}$, Mathai $\mathrm{M}$, van den Broek N. Implementing maternal death surveillance and response: $A$ review of lessons from country case studies. BMC Pregnancy Childbirth. 2017 Jul 17;17(1).

2. Mgawadere F, Unkels R, van den Broek $\mathrm{N}$. Assigning cause of maternal death: a comparison of findings by a facility-based review team, an expert panel using the new ICD-MM cause classification and a computerbased program (InterVA-4). BJOG An Int J Obstet Gynaecol. 2016 Sep 1;123(10):164753.

3. Moran AC, Jolivet RR, Chou D, Dalglish SL, Hill K, Ramsey K, et al. A common monitoring framework for ending preventable maternal mortality, 2015-2030: Phase I of a multi-step process. BMC Pregnancy Childbirth. 2016 Aug 26;16(1).

4. Trends in maternal mortality: 1990 to 2015 : estimates by WHO, UNICEF, UNFPA, World Bank Group and the United Nations Population Division. Geneva: World Health Organization; 2015. 2015;

5. Hoelman MB, Parhusip BTP, Eko S, Bahagijo $\mathrm{S}$, Santono H. Sustainable Development Goals-SDGs Panduan Untuk Pemerintah Daerah (Kota dan Kabupaten) dan Pemangku Kepentingan Daerah. Sustain Dev. 2016;192.

6. $\mathrm{WHO} \mid$ Strategies toward ending preventable maternal mortality (EPMM). WHO. 2016;

7. Kemenkes RI. Profil Kesehatan Indonesia 2016 [Internet]. Profil Kesehatan Provinsi Bali. 2017. 1-220 p. Available from: http:// www.depkes.go.id/resources/download/ pusdatin/profil-kesehatan-indonesia/ProfilKesehatan-Indonesia-2016.pdf
8. Dinas Kesehatan Propinsi Jawa Timur. Profil Kesehatan Tahun 2017. 2017.

9. Dinas Kesehatan Kabupaten Kediri. Profil Kesehatan Tahun 2018. 2018.

10.Lindquist JD, Vogelzang RL. Pelvic Artery Embolization for Treatment of Postpartum Hemorrhage. Semin Intervent Radiol. 2018;35(1):41-7.

11. Nsangamay T, Mash R. How to improve the quality of care for women with postpartum haemorrhage at Onandjokwe Hospital, Namibia: Quality improvement study. BMC Pregnancy Childbirth. 2019;19(1):1-9.

12. Committee WH, Counci RB and. Management of Postpartum Haemorrhage (PPH). R Aust New Zeal Coll Obs Gynaecol [Internet]. 2017;(May 2015):1-14. Available from: https:// www.ranzcog.edu.au/RANZCOG_SITE/ media/RANZCOG-MEDIA/Women \%27s Health/Statement and guidelines/ClinicalObstetrics/Management-of-PostpartumHaemorrhage-(C-Obs-43)-ReviewJuly-2017.pdf?ext=.pdf

13. Thakur M, Adekola HO, Asaad R, Gonik B. Secondary Postpartum Hemorrhage due to Spontaneous Uterine Artery Rupture after Normal Vaginal Delivery Managed by Selective Arterial Embolization. AJP Rep. 2016 Oct 1;6(4):e442-4.

14. Zubor P, Kajo K, Dokus K, Krivus S, Straka $L$, Bodova KB, et al. Recurrent secondary postpartum hemorrhages due to placental site vessel subinvolution and local uterine tissue coagulopathy. BMC Pregnancy Childbirth. 2014 Feb 21;14(1).

15. Probandari A, Arcita A, Kothijah K, Pamungkasari EP. Barriers to utilization of postnatal care at village level in Klaten district, central Java Province, Indonesia. BMC Health Serv Res. 2017 Aug 7;17(1).

16. Kementerian Kesehatan RI. Profil Kesehatan Indonesia Tahun 2017 [Internet]. 2017. 496 p. 
Available from: website: http://www.kemkes. go.id

17. Kayen Kidul Community Health Center. Monitoring Local Area Maternal and Child Health. 2019.

18. Sakala B. An evidence-based policy brief: improving the quality of postnatal care in mothers 48 hours after childbirth. Malawi Med J. 2019;31(2):164.

19. Mohan D, Gupta S, LeFevre A, Bazant $E$, Killewo J, Baqui AH. Determinants of postnatal care use at health facilities in rural Tanzania: Multilevel analysis of a household survey. BMC Pregnancy Childbirth [Internet]. 2015;15(1):1-10. Available from: http:// dx.doi.org/10.1186/s12884-015-0717-7

20. Pinaringsih T, Riyanti E, Kusumawati A. Faktor-Faktor Yang Berhubungan Dengan Niat Kunjungan Ibu Nifas Ke Pelayanan Kesehatan Di Wilayah Kerja Puskesmas Tlogosari Kulon Kota Semarang. J Kesehat Masy. 2017;5(3):653-60.

21. Chaka EE, Abdurahman AA, Nedjat $S$, Majdzadeh R. Utilization and Determinants of Postnatal Care Services in Ethiopia: A Systematic Review and Meta-Analysis. Ethiop J Health Sci. 2019;29(1):935-44.

22. Berhe A, Bayray A, Berhe Y, Teklu A, Desta $A$, Araya $T$, et al. Determinants of postnatal care utilization in Tigray, Northern Ethiopia: A community based cross-sectional study. PLoS One. 2019;14(8):e0221161.

23. Ulfa ZD, Kuswardinah A, Mukarromah SB. Faktor-Faktor Yang Mempengaruhi Pemanfaatan Pelayanan Kesehatan Maternal Secara Berkelanjutan. Public Heal Perspect J. 2018;2(2):184-90.

24. Ochieng CA, Odhiambo AS. Barriers to formal health care seeking during pregnancy, childbirth and postnatal period: a qualitative study in Siaya County in rural Kenya. BMC Pregnancy Childbirth. 2019;19(1):1-14.

25. Akibu M, Tsegaye W, Megersa T, Nurgi S. Prevalence and Determinants of Complete Postnatal Care Service Utilization in Northern Shoa, Ethiopia. J Pregnancy. 2018;2018.

26. Dolapo Somefun O, Ibisomi L. Determinants of postnatal care non-utilization among women in Nigeria. BMC Res Notes [Internet]. 2016 [cited 2019 Oct 17];9:21. Available from: http://creativecommons.

27. Limenih MA, Endale ZM, Dachew BA. Postnatal Care Service Utilization and Associated Factors among Women Who Gave Birth in the Last 12 Months prior to the Study in Debre Markos Town, Northwestern Ethiopia: A Community-Based Cross-Sectional Study. Int J Reprod Med. 2016;2016:1-7.

28. Langlois É V, Miszkurka M, Zunzunegui MV, Ghaffar A, Ziegler D, Karp I. Inequities in postnatal care in low- and middleincome countries: a systematic review and meta-analysis. Bull World Health Organ. 2015;93(4):259-270G.

29. Dahiru T, Oche OM. Determinants of antenatal care, institutional delivery and postnatal care services utilization in Nigeria. Pan Afr Med J. 2015;21:1-17.

30. Gebrehiwot G, Medhanyie AA, Gidey G, Abrha K. Postnatal care utilization among urban women in northern Ethiopia: Crosssectional survey. BMC Womens Health. 2018;18(1):1-10.

31. Chen L, Qiong W, van Velthoven $\mathrm{MH}$, Yanfeng Z, Shuyi Z, Ye L, et al. Coverage, quality of and barriers to postnatal care in rural Hebei, China: A mixed method study. BMC Pregnancy Childbirth. 2014;14(1). 